\title{
ПОБУДОВА ЕКОНОМЕТРИЧНИХ ФУНКЦЙ ПОПИТУ НА КРЕДИТИ ТА ПРОПОЗИЦІї ДЕПОЗИТІВ УКРАЇНСЬКОГО БАНКУ
}

\author{
ПОСТРОЕНИЕ ЭКОНОМЕТРИЧЕСКИХ ФУНКЦИЙ СПРОСА НА КРЕДИТЫ И \\ ПРЕДЛОЖЕНИЯ ДЕПОЗИТОВ УКРАИНСКОГО БАНКА
}

\section{THE ECONOMETRIC LOAN DEMAND AND DEPOSIT SUPPLY FUNCTIONS CONSTRUCTION}

В статті розглядається моделювання функиії попиту на кредити та функції пропозииії депозитів комериійного банку. Наведено методику підготовки даних для побудови таких моделей - від вихідних даних на рівні індивідуальних угод. На прикладі украӥнського банку, використовуючи підготовлені дані, були побудовані регресійні економетричні моделі залежності обсягів кредитів від кредитної ставки та обсягів депозитів від депозитної ставки. Була проведена оиінка тісноти зв'язку кредитної ставки з обсягами виданих кредитів та оцінка тісноти зв'язку депозитної ставки з обсягами залучених депозитів та виявлено, щуо за коеріиієнтом детермінації моделі є достатньо точними. Аналіз залишків моделей показав, щз моделі є також $і$ адекватними, оскільки залишки мали нульове математичне сподівання, були незалежними та мали нормальний розподіл. Таким чином були побудовані регресійні економетричні моделі попиту на кредити та пропозиції депозитів українського банку, щзо $\epsilon$ точними та адекватними та можуть бути використані при моделюванні банку.

Ключові слова: попит на кредити, пропозиція депозитів, ціноутворення в банку, моделювання ціноутворення в банку.

В статье рассматривается моделирование функции спроса на кредиты и функиии предложения депозитов коммерческого банка. Приведено методику подготовки данных для построения таких моделей - начиная с входных данных на уровне индивидуальных договоров. На примере украинского банка, используя подготовленные данные, были построены регрессионные эконометрические модели зависимости объёмов кредитов от кредитной ставки и объёмов депозитов от депозитной ставки. Была проведена оченка тесноты связи кредитной ставки с объемами выланных кредитов и депозитной ставки с объемами привлеченных депозитов и выявлено, что за коэффициентом детерминации модели являются достаточно точными. Анализ остатков моделей показал, что модели также являются адекватныли, так как остатки имели нулевое математическое ожидание, были независимыми и имели нормальное распределение. Таким образом были построены регрессионные эконометрические модели спроса на кредиты и предложения депозитов, которые являются точными и адекватными и могут использоваться при моделировании банка.

Ключевые слова: спрос на кредиты, предложение депозитов, ценообразование в банке, моделирование ценообразования в банке.

The paper describes the modelling of commercial bank loan demand function and deposit supply function. Loan demand function and deposit supply function are key elements in bank pricing models. Nevertheless, it is hard to create them due to great variation in commercial bank products, 
terms and options. We propose the methodology on how to prepare raw banking data for creation of regression models. Using one of biggest Ukrainian banks'data, we assessed the correlation between volumes of loans and deposits with respective load and deposit rates. Linear loan demand function and linear deposit supply function were created using these data. We found that these models were precise adequate and could be used for bank pricing modelling. In conclusion were discussed the limitations of obtained models, possible areas of usage and perspectives of further research.

Keywords: loan demand, deposit supply, bank pricing, bank pricing modelling.

Вступ. Банки є важливими фінансовими посередниками в економіці країни. Результат їх діяльності впливає на всю економіку: швидкість розвитку виробництва через механізми кредитування та інвестування, забезпечення валютних операцій експорту-імпорту та різноманітних платежів, збереження та примноження заощаджень.

Прибуткова i стабільна діяльність банків таким чином впливає на стабільність соціально-економічної ситуації в країні та швидкість економічного зростання. Проте ця прибуткова і стабільна діяльність банків базується на чіткому виконанні зобов'язань, які беруть на себе кредитори банку. У випадку, коли кредитори повертають взяті кредити невчасно (із деяким запізненням), це ставить банк в ситуацію відсутності коштів в конкретний момент для виконання взятих зобов'язань щодо зберігання депозитів та повернення їх в певний момент, а також зменшення прибутковості від упущеної вигоди інвестування чи кредитування повернених коштів.

Штрафи за невчасне повернення, які практикують банки, щоб зменшити це явище, не вирішують його повністю, таким способом банки лише компенсують зусилля із додаткового залучення коштів для виконання зобов'язань. Водночас, штрафи не захищають від ситуації, якщо потрібно виконувати зобов'язання, але кредит не був повернений вчасно і банк не має змоги залучити кошти для виконання своїх зобов'язань.

В даній роботі розглядається процес вибору кредитної та депозитної ставок (відсотків за кредитами та вкладами) i термін «ціноутворення» тут використовуємо саме у цьому сенсі. Ціноутворення - одна із ключових задач в банківській діяльності, і від неї залежить чи врахує банк наявні на ринку ризики, чи буде прибутковим. Деякі підходи при ціноутворенні полягають у використанні мікроекономічних функції попиту на кредити та функції пропозиції депозитів, за допомогою яких можна знайти оптимальні 3 точки зору прибутку кредитну та депозитну ставку. Тому моделювання функцій попиту на кредити та пропозиції депозитів є дуже важливим для ціноутворення кредитів та депозитів.

Питаннями ціноутворення в банківській діяльності займалися українські та зарубіжні дослідники: Азаренкова [1], Владичин [2], Вовчак [3], Волошин І.В. [47, 9-11], Волошин М.I. [5, 8-11], Гришин [12-14], Іваненко [12, 14], Кляйн [15], Козак [14, 16], Куц [14], Монті [17], Осіпенко [18-21].

Владичин в [2] наводить шість способів ціноутворення кредитів банку, проте лише половина 3 них враховують кредитний ризик, та в жодному не розкривається конкретний механізм такої оцінки чи врахування несвоєчасного повернення кредитів при ціноутворенні. В роботі [3] приводиться загальний 
алгоритм ціноутворення на кредитні продукти в Україні, проте у цьому підході до ціноутворення не враховується кредитний ризик чи можливість випадкового запізнення при поверненні кредиту. Автор явно зазначає, що необхідне врахування кредитного ризику при ціноутворенні на кредити.

В моделі Монті-Кляйна $[15,17]$ розглядається випадок банку-монополіста, для якого відома функція попиту на кредити та пропозиції депозитів, i банк може залучати депозити і видавати кредити відповідно до цих функцій попитупропозиції. Особливістю цих функцій $є$ те, що в них кредитна та депозитна ставки залежать від обсягів кредитів та депозитів відповідно, які вирішить залучити банк. Це обгрунтовується тим, що розглядається ринок ідеальної конкуренції, на якому банк не впливає на ринкові кредитну та депозитну ставки, а змушений по суті використовувати їх, проте може обирати які обсяги кредитів та депозитів залучити. Ця модель відноситься до категорії мікроекономічних моделей, де відповідно до теорії фірми банк розглядається як специфічна фірма, в якій гроші є товаром. Недоліком такої моделі для питання щодо оптимального ціноутворення $\epsilon$ те, що по суті ціна кредитів та депозитів в ній не визначається, а $\epsilon$ заданою екзогенно. Також ця модель статична, не дозволяє розглядати ціноутворення в часі, а тим паче розглянути випадок запізнення при поверненні кредитів та депозитів.

Одним із підходів моделювання банківської діяльності, є моделювання ціноутворення в банку із врахуванням різних видів ризиків. Відповідно до цього підходу, кредитна чи депозитна ставка визначається як сума базової ставки і доданку, що враховує той чи інший ризик чи кілька ризиків водночас. Наприклад, в роботі [7] розглядається ціноутворення роздрібних депозитів з урахуванням ризику перевкладення, тобто що після закінчення терміну депозиту депозитори не перевкладуть гроші на новий термін, а заберуть їх з банку взагалі. Знаючи імовірність того, що вкладник не захоче перевкласти гроші, можна вирахувати депозитну ставку, що нівелювала би ризик перевкладення. А в роботі [8] розглядається ціноутворення на роздрібні депозити 3 урахуванням ризику ліквідності. В роботі [11] розглядається ціноутворення активів з урахуванням кредитного ризику та ризику ліквідності на основі матриці фінансування, що пов'язує пасиви банку з різним терміном вкладання з активами банку, адже поширеною $є$ ситуація, коли довготермінові кредити фінансуються за рахунок короткотермінових депозитів, чи кількох депозитів із різними термінами вкладення. В роботі [9] було розглянуто модель банку, що враховувала при ціноутворенні кілька ризиків водночас - кредитного, ринкового, операційного та ризику ліквідності на основі підходу «Грошовий потік під ризиком» (Cash-flow at risk approach).

Також поширеним є підхід до моделювання банку як системи вхідних та вихідних грошових потоків $[1,4,14,16]$. Відповідно до цього підходу, розглядаються вхідні та вихідні грошові потоки банку з різним рівнем деталізації. Поширеними задачами, що ставляться при використанні цього підходу $\epsilon$ контролінг діяльності банків, виявлення та попередження можливих негативних для банку явищ. Одним із варіантів використання цього підходу є методологія 
геп-аналізу, що дозволяє виявити розриви ліквідності для банку та прийняти рішення щодо стимулювання залучення коштів чи пошук альтернативних джерел коштів для підтримання ліквідності в необхідний момент.

Окремий напрямок досліджень комбінує підхід теорії керування, системну динаміку Форрестера, еконофізику, підхід до моделювання банку як виробничої фірми (Industrial Organization Approach). В цьому підході використовуються економіко-математичні моделі, що розглядають банк 3 точки зору теорії керування, здійснюючи на нього керуючі впливи. При деяких збуреннях, на які той, хто керує, не має впливу та при керуванні, яке доступне, результатом роботи банку є певний показник. Керування здійснюється з метою досягнення бажаної поведінки цього результуючого показника.

В рамках цього підходу в роботі [12] було запропоновано розглядати банк 3 точки зору теорії керування, та визначено що є керуванням у банку (це кредитні та депозитні ставки), що є збуреннями (пропонувалися варіації обсягів кредитів, що повертаються кредиторами банку та депозитів, що повертає банк), що $\epsilon$ фазовою (результуючою) змінною (прибуток банку). В роботах [4, 13] було описано деякі вхідні та вихідні потоки банку, зокрема до вхідних відносяться залучені банком депозити та повернені з відсотками кредити, до вихідних повернені банком депозити 3 відсотками та видані кредити, водночас допускалися і інші вхідні та вихідні потоки, відповідно до банківської діяльності.

В роботі [18] було описано економіко-математичну динамічну модель банку, в якій кредитні та депозитні потоки, зазначені вище, задані через лінійні функції кредитів та депозитів. Водночас до моделі додавався міжбанківський ринок та була постановка деяких задач керування, зокрема задача оптимального керування кредитною та депозитною ставками за умови, що всі залучені депозити видаються як кредити, без міжбанківського ринку, впливу власного капіталу банку та часткового резервування. Для деяких задач була задана лише постановка, без отриманих результатів.

В роботі [14] було описано подібну економіко-математичну модель 3 лінійними функціями кредитів та депозитів, де обсяги залежали від кредитної та депозитної ставок відповідно із врахуванням невизначеності в обсягах повернених депозитів та кредитів, була сформульована постановка задачі керування, але не отримано їі розв'язку. Також було розглянуто два критерії керування - максимізація процентного доходу банку та максимізація власного капіталу банку.

В роботах [5, 10] було розглянуто економіко-математичну модель для задачі ціноутворення на роздрібні строкові вклади та було отримано оптимальну депозитну ставку за допомогою методів теорії детермінованого управління відносно ринкової ставки. Було використано потоковий підхід та фіксовану дохідність по активам (кредитам). Таким чином, модель не враховувала ціноутворення за кредитами і запізнення при поверненні кредитів та депозитів. В роботі [6] було розглянуто економіко-математичну динамічну модель для задачі ціноутворення на роздрібні кредити відносно ринкового рівня з використанням скорингового балу відсікання. За допомогою комп'ютерного моделювання було 
показано залежності залишків робочих кредитів, рівня дефолтів у портфелі банку, відсоткової ставки по кредиту та скорингового балу відсікання в залежності від часу. Таким чином, попри динамічність модель не враховувала запізнення при поверненні кредитів.

Інший спосіб комбінування ціноутворення на кредити із врахуванням кредитного скорингу було розглянуто в динамічній моделі [19-21]. Автор інтегрував в наявну динамічну модель, розглянуту в [18], систему кредитного скорингу в рамках вхідного потоку кредитного контуру.

В деяких з цих роботах з ціноутворення взагалі не розглядається часовий аспект запізнення при поверненні кредитів, а лише підходи до оцінки кредитного ризику та врахуванні кредитного ризику при ціноутворенні без детального розгляду випадкового запізнення в часі. Водночас для застосування потокової моделі банку на практиці є потреба у побудові функції попиту на кредити та функції пропозиції депозитів, які можна використовувати для моделювання ціноутворення.

Постановка завдання. Мета статті - перевірити чи доцільно для українського комерційного банку будувати функцію попиту на кредити та функцію пропозиції депозитів, що $\epsilon$ одними 3 ключових моментів при моделюванні ціноутворення за допомогою потокової моделі банку. Для досягнення цієї мети розглянемо методику підготовки банківських даних для побудови функції попиту на кредити та функції пропозиції депозитів; оцінимо тісноту зв'язку обсягів виданих кредитів і кредитної ставки, обсягів залучених депозитів і депозитної ставки; побудуємо функцію попиту на кредити та функцію пропозиції депозитів; оцінимо точність та адекватність цих функцій.

Методологія. При обробці статистичної інформації банку слід врахувати деякі моменти. По-перше, оскільки функція попиту на кредити через коефіцієнти $K$ i $b$ відображає певну ринкову ситуацію і становище банку на ринку, вона $\epsilon$ актуальною відносно короткий період часу - поки конкурента ситуація на ринку чи сукупний попит суттєво не змінюються. Тому в реаліях України не можна брати статистичну інформацію за всі роки роботи банку чи навіть за кілька років, бо зміни за такий період суттєві. Найкраще обирати якомога короткий період часу - місяць чи кілька місяців.

3 іншого боку, на короткому періоді часу може бути заключено занадто мало кредитних та депозитних договорів, для того щоб вважати такі дані статистично значимими. Кількість кредитних та депозитних договорів залежить від розміру банку, їх маркетингової активності, для великого банку за період в місяць може бути достатньо багато договорів, для невеликого - лише десятки. А також, банки зазвичай змінюють кредитні та депозитні ставки не дуже часто, зазвичай раз на кілька тижнів чи місяців, тому за короткий період часу може не бути хоча б кількох різних кредитних чи депозитних ставок для того щоб можна було побудувати певну функцію залежності обсягу залучених депозитів чи виданих кредитів від відповідних ставок.

Варто зазначити, що час від часу банку вдається оформити договір на особливо велику суму грошей, і цей обсяг однієї кредитної чи депозитної операції 
залежить більше не від діяльності банку, а від характеристик клієнта банку позичальника чи депозитора. Такі аномальні дані слід вилучати 3 наявних статистичних даних, бо вони за рахунок великого обсягу можуть спотворювати вигляд залежності. Також аномальними можуть бути і ставки: для деяких клієнтів банк може ставити аномально малі відсоткові ставки чи взагалі нульову ставку, такі дані також слід вилучати з статистичних даних, за якими будуть будуватися функції попиту на кредити та пропозиції депозитів.

Типово, дані представлені в банках по договорам - тобто для кожної окремої операції з заключення кредитного чи депозитного договору заноситься в базу даних дати початку та кінця дії договору, сума договору, валюта, термін видачі кредиту чи вкладання депозитів, умови даного кредитного чи депозитного продукту та інші деталі.

Оскільки дані збираються у розрізі по одному договору, то для того щоб отримати дані для відповідних періодів часу - потижнево чи помісячно, необхідно їх агрегувати. Для цього достатньо суми додати, а для ставок використати середньозважене значення.

Зазвичай банки мають по кілька кредитних та депозитних продуктів водночас. Окрім того, вони оформлюються на різні терміни. При цьому ставки для різних термінів зазвичай неоднакові. Для депозитів у більшості випадків депозитна ставка збільшується при збільшенні терміну до одного року, а при дуже великих періодах вкладання - трохи менша. Для кредитів на короткі терміни ставка зазвичай велика, на терміни від року до п’яти - десяти збільшується, а на дуже великі терміни трохи менша від максимальної.

За таких обставин, для побудови функції попиту на кредити не варто використовувати дані про кредити, видані на різні терміни, бо зміни ставок в залежності від різних термінів можуть бути більшими від змін ставок у часі для одного і того ж терміну видачі кредитів. Тому доцільно брати дані для певного одного терміну, на який видаються кредити. Наприклад, найпопулярнішим терміном виданих кредитів в досліджуваному банку $\epsilon$ період в 5 років 3 невеликими варіаціями (1822-1826 днів). Такі договори і доцільно розглядати для побудови функції попиту на кредити.

Результати дослідження. Розглянемо підхід до побудови функції попиту на кредити та функції пропозиції депозитів на прикладі одного з банків України, що Національний банк України відносить до першої групи відповідно до своєї класифікації.

Цей банк є універсальним комерційним банком, працює як з фізичними, так і $з$ юридичними особами, не обслуговує інтереси якоїсь окремої промислової групи, тому є хорошим прикладом комерційного банку, метою якого є отримання прибутку. Через домовленість щодо нерозголошення інформації, назва банку не може бути озвучена в цій роботі.

Отже, необхідно отримати функцію попиту на кредити, тобто залежність обсягів виданих кредитів від кредитної ставки та наявних зобов'язань банку. Для цього доцільно скористатися загальним виглядом функції попиту на кредити, що був розглянутий авторами в попередніх дослідженнях: 


$$
f_{K}\left(t, u_{K}(t), x(t)\right)=\min \left(x(t)+D_{i n}(t), K-b \cdot u_{k}(t)\right)
$$

Де

$f_{K}(\cdot)$ - функція попиту на кредити;

$\mathrm{x}(t)$ - капітал комерційного банку в момент часу $t$;

$D_{\text {in }}(t)$ - обсяг залучених депозитів;

$u_{K}(t)$ - кредитна ставка в момент часу $t$;

$K, b$ - коефіцієнти лінійної залежності.

Вона враховує той нюанс, що банк видає кредити відповідно до функції попиту на кредити, але в рамках наявних зобов'язань та власного капіталу. Зобов'язання можна розрахувати 3 відповідної функції пропозиції депозитів, власний капітал - 3 балансу банку. А функцію попиту на кредити можна отримати із статистичної інформації.

Слід зазначити, що хоча $K$ і $b$ вводяться лише як коефіцієнти, можна надати їм трактування в економічному сенсі.

При нульовій кредитній ставці (тобто, мінімально допустимій для банку в цій роботі) обсяг виданих кредитів становитиме $K$, тому цей коефіцієнт можна трактувати як інвестиційну ємність ринку, максимальний обсяг попиту на кредити. Відповідно до лінійної функції попиту вважається, що він не $\epsilon$ необмеженим, оскільки перетинає вісь ординат в деякій точці.

Від коефіцієнта $b$ залежить, на яку величину зміниться обсяг виданих кредитів, якщо змінити на певну величину кредитну ставку, тому його можна трактувати як деякий аналог еластичності попиту на кредити (виражений не у відсотках) - чутливість до зміни кредитної ставки. Можна трактувати цей показник, як рівень конкуренції, при збільшенні конкурентної боротьби, він буде вищим. Таким чином модель неявно враховує існування на ринку інших банківських установ. Комбінацію цих показників можна вважати ринковими умовами.

Із врахуванням значених в методології підходів, дані щодо обсягів виданих кредитів та кредитних ставок для розглядуваного банку матимуть вигляд, як на рис. 1.

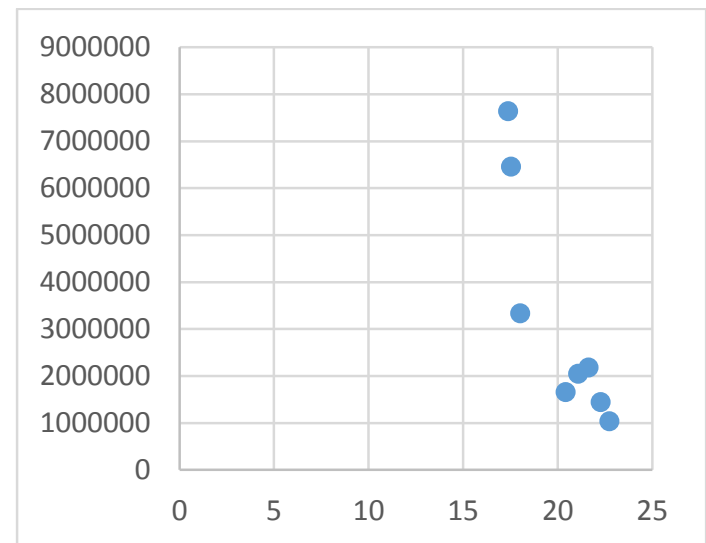

Рис. 1. Обсяги виданих кредитів та кредитні ставки для розглядуваного банку за 2012 рік, одна точка - дані за місяць

Для дотримання домовленості щодо нерозголошення даних, абсолютні 
значення виданих кредитів були лінійно змінені (таким чином характер розташування точок на графіку не змінився). Розглядалися кредити з терміном видачі на 5 років, 3 виключенням даних із аномально низькими кредитними ставками чи аномально великими обсягами виданих кредитів, дані за 2012 рік агреговані помісячно.

За допомогою вказаних даних можна отримати функцію попиту на кредити шляхом побудови функції регресії що за допомогою методу найменших квадратів апроксимуватиме певну функціональну залежність до наявних даних. В даному випадку добре себе зарекомендувала навіть лінійна функція залежності, що $\mathrm{\epsilon}$ зручною і для аналізу, і для комп'ютерного моделювання (операції множення та додавання-віднімання вимагають мало комп'ютерного часу).

Лінійну функцію попиту для вказаних даних можна бачити на Рис. 2.

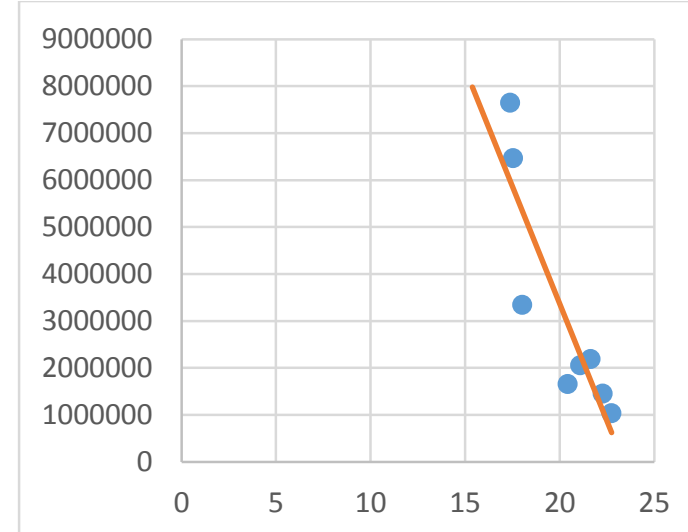

Рис. 2. Функція попиту на кредити (лінія)

Функція попиту на кредити, що представлена на Рис. 2, має такий вигляд:

$f_{K}\left(t, u_{K}(t), x(t)\right)=\min \left(x(t)+D_{\text {in }}(t), 23364809-99964500 \cdot u_{k}(t)\right)$

Кредитна ставка при цьому має бути представлена десятковим дробом по відношенню до одиниці. Наприклад, ставка 25\% має бути виражена числом 0,25.

Вказана функція регресії є доволі точною: коефіцієнт кореляції становить 0,8830; коефіцієнт детермінації задовільний і становить 0,7797 .

Що ж до адекватності моделі, то її теж можна вважати адекватною:

1. м математичне сподівання залишків наближене до 0 ;

2. графік залишків моделі не демонструє функціональної нелінійної залежності (див. Рис. 3);

3. д дисперсія залишків є стабільною;

4. нормалізовані залишки знаходяться в інтервалі від -2 до 2, тобто відповідають тому факту що для нормального розподілу 3 математичним сподіванням 0 i середньоквадратичним ухилом 1 , 95\% значень будуть знаходитися в цьому інтервалі;

5. відсутня автокореляція залишків (кореляція 1 порядку складає 0,00937938481257581 і є близькою до нуля; для інших порядків трохи вища, але все ще не демонструє рівня наявності залежності);

6. залишки розподілені відповідно до нормального закону розподілу. 


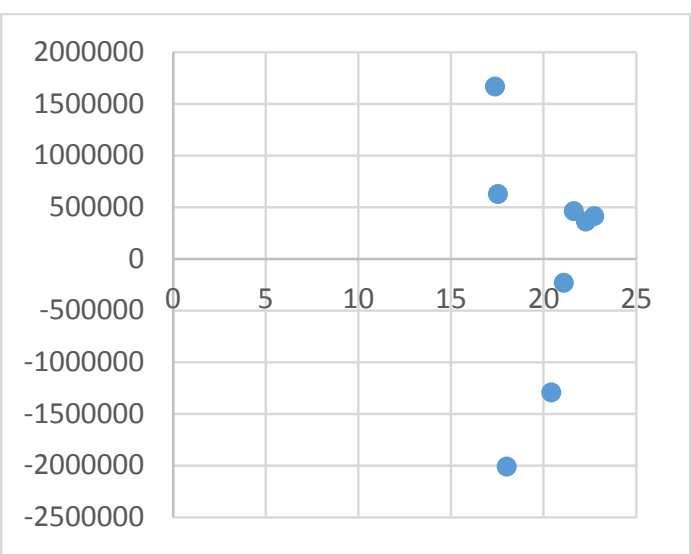

Рис. 3. Графік залежності відхилень лінійної моделі попиту на кредити в залежності від кредитної ставки та фактичних значень обсягів виданих кредитів

Аналогічно наведеному підходу, дані щодо обсягів залучених депозитів та депозитних ставок для розглядуваного банку матимуть вигляд, як на Рис. 4.

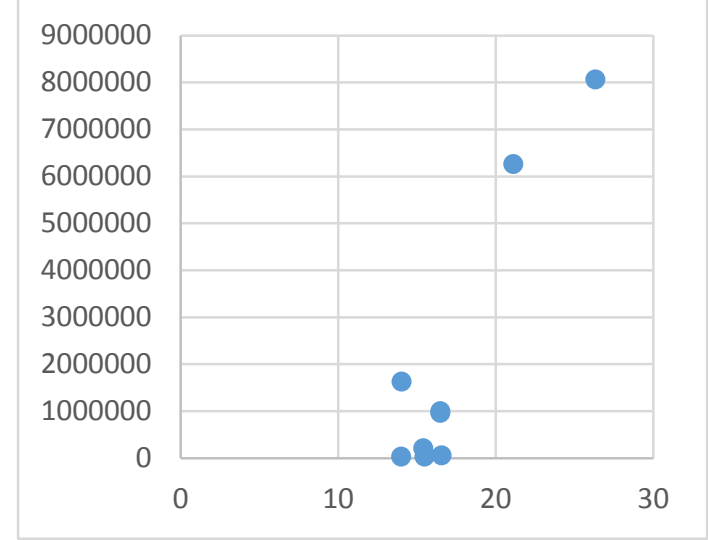

Рис. 4. Обсяги залучених депозитів та депозитні ставки для розглядуваного банку за 2012 рік, одна точка - дані за місяць

Розглядалися депозити з терміном залучення на 1 рік, з виключенням даних із аномально великими обсягами залучених депозитів, дані за 2012 рік агреговані помісячно.

За допомогою вказаних даних можна отримати функцію пропозиції депозитів шляхом побудови функції регресії, що за допомогою методу найменших квадратів апроксимуватиме певну функціональну залежність до наявних точок даних.

В даному випадку добре себе зарекомендувала лінійна функція залежності, що $\epsilon$ зручною i для аналізу, i для комп'ютерного моделювання (операції множення та додавання-віднімання вимагають мало комп'ютерного часу). Що цікаво, нелінійні функції залежності показували меншу точність апроксимації.

Лінійну та нелінійні функції пропозиції депозитів для вказаних даних можна бачити на Рис. 5. 


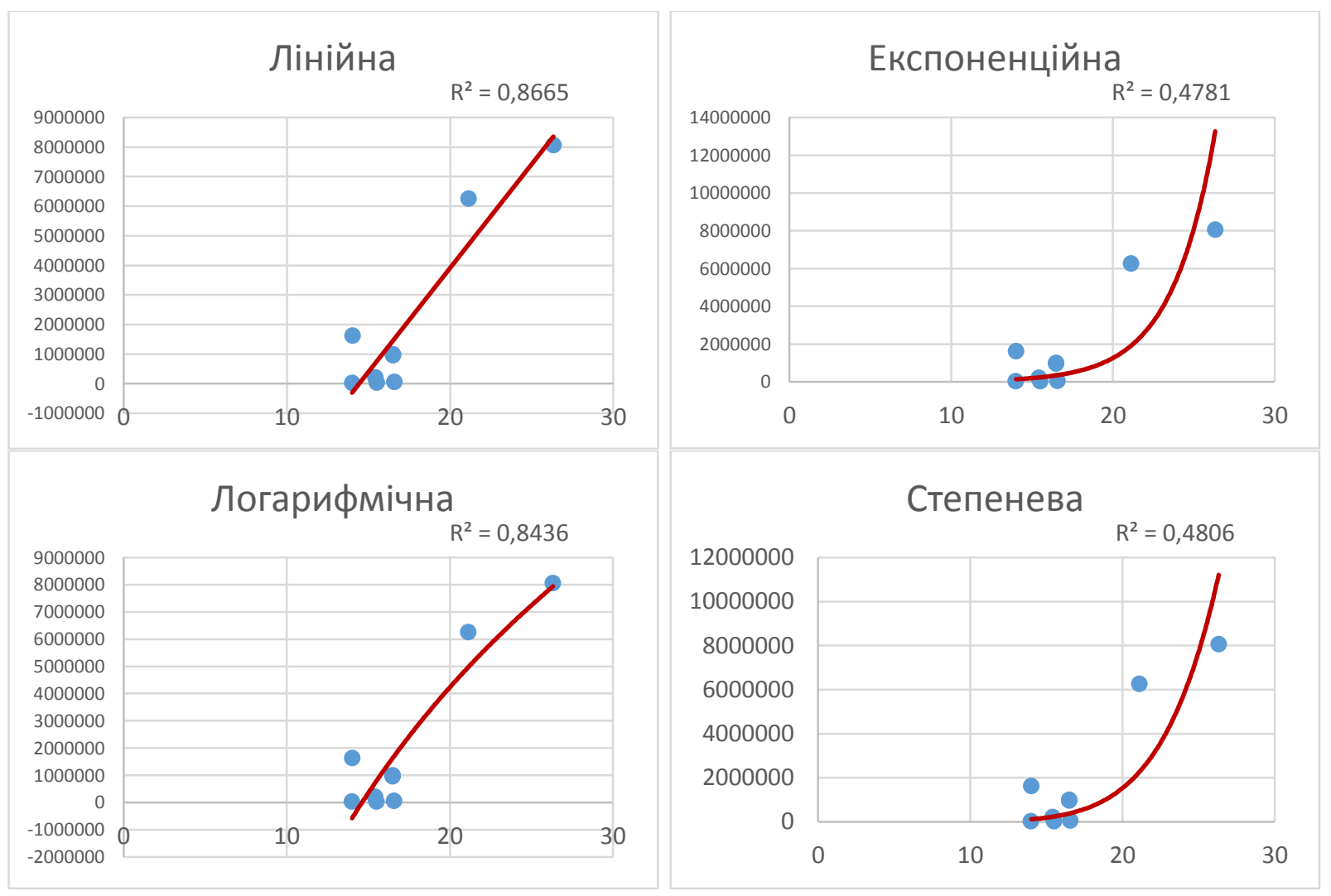

Рис. 5. Функції пропозиції депозитів

Лінійна функція пропозиції депозитів, що представлена на Рис. 6, має такий вигляд формулою:

$$
\left.f_{D}\left(t, u_{D}(t), x(t)\right)=-10147183+70268357 \cdot u_{d}(t)\right)
$$

Депозитна ставка при цьому має бути представлена десятковим дробом по відношенню до одиниці.

Вказана функція регресії є доволі точною: коефіцієнт кореляції становить 0,9308; коефіцієнт детермінації задовільний і становить 0,8665 .

Що ж до адекватності моделі, то її теж можна вважати адекватною:

1. м математичне сподівання залишків рівне 0 ;

2. графік залишків моделі не демонструє функціональної нелінійної залежності (див. Рис. 6);

3. дисперсія залишків є стабільною;

4. нормалізовані залишки знаходяться в інтервалі від -2 до 2, тобто відповідають тому факту що для нормального розподілу 3 математичним сподіванням 0 i середньоквадратичним ухилом 1 , 95\% значень будуть знаходитися в цьому інтервалі;

5. відсутня автокореляція залишків (кореляція 1 порядку складає 0,34393, що не $\epsilon$ значимим рівнем; для інших порядків так само не демонструє рівня наявності залежності);

6. залишки розподілені відповідно до нормального закону. 


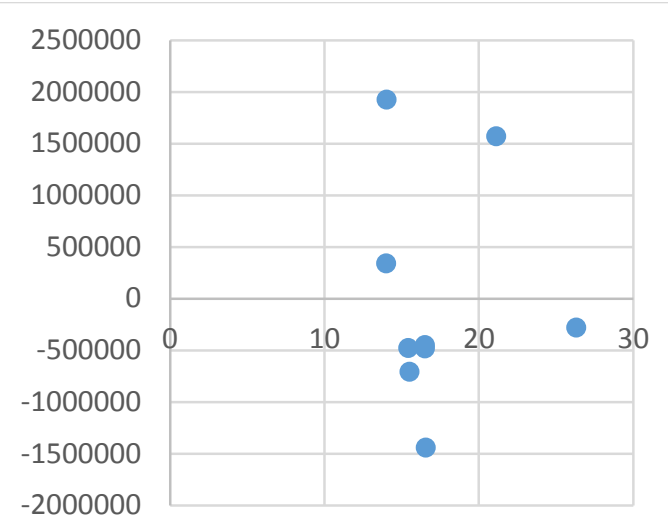

Рис. 6. Графік залежності відхилень лінійної моделі пропозиції депозитів в залежності від депозитної ставки та фактичних значень обсягів залучених депозитів

Висновки. Таким чином, на основі даних банку України, наведений приклад побудови функцій попиту на кредити та пропозиції депозитів. Їх можна використовувати для комп'ютерного моделювання оптимальних кредитних та депозитних ставок даного банку відповідно до прогностичних можливостей потокової моделі, що базується на отриманих функціях попиту на кредити та пропозиції депозитів.

Даний підхід до побудови функції попиту на кредити та функції пропозиції депозитів, а також модель ціноутворення на їх основі можна використовувати для банків будь-якого розміру, за умови, що можна буде побудувати достатньо точні та адекватні моделі попиту на кредити та пропозиції депозитів в залежності від кредитної та депозитної ставок відповідно. Моделювання ціноутворення можна проводити з кроком в день, тиждень, місяць, рік, чи якусь іншу кількість днів, проте це буде залежати від наявних статистичних даних: для багатьох українських банків найменшим можливим кроком буде один місяць, через відносно невеликі обсяги операцій і статистики відповідно.

Модель дозволяє визначити оптимальні кредитні та депозитні ставки деякого базового кредитного та депозитного продукту за рахунок використання функцій попиту на кредити та пропозиції депозитів. Якщо ж можливо побудувати функції попиту на кредити для кожного кредитного продукту, то модель можна використати для ціноутворення кожного кредитного продукту (відповідно і 3 депозитними продуктами). Наразі ж рекомендується використовувати іiі для пошуку оптимальних ставок для деяких базових продуктів.

3 цієї причини, доцільно брати функцію попиту на кредити для кредитів для фізичних осіб на тривалий термін (в умовах України - 5-10 років), бо такий кредитний продукт характеризується деякою стандартністю умов для різних позичальників, на відміну від короткострокових споживчих кредитів та кредитів для юридичних осіб, що можуть мати ледве не різні умови для кожної 3 
юридичних осіб. Депозитні продукти характеризуються більшою стандартністю умов для депозиторів, проте на вартість короткострокових депозитів можуть впливати результати геп-аналізу, прагнення банку відкоригувати свою ліквідність, тому теж рекомендуємо використовувати модель для депозитів на більший термін (в умовах України - 1 рік).

Вважається, що регресійні моделі часових рядів будуть достатньо точними на проміжках часу, рівними близько третині від проміжку часу, з якого бралися вихідні дані. Враховуючи ту обставину що функції попиту на кредити та пропозиції депозитів імовірно змінюються з часом під впливом зміни факторів попиту та пропозиції, конкуренції та ринкового середовища, відповідно і їх варто використовувати лише на проміжку часу в третину від часу, протягом якого збиралися дані. Зменшити негативні наслідки таких обмежень можна шляхом регулярного калібрування функцій попиту на кредити та пропозиції депозитів із врахуванням все нових даних.

Використання функцій попиту на кредити та пропозиції депозитів відкриває перспективи для моделювання ціноутворення комерційного банку в умовах випадкового запізнення при поверненні кредитів, що дозволить обмежити негативний вплив несвоєчасного повернення кредитів. Подальші дослідження в напрямку кращої підготовки вихідних банківських даних, отримання більш точних функцій попиту на кредити та пропозиції депозитів, врахування інших, нецінових факторів дозволить розвинути моделювання ціноутворення до такого рівня, що банки зможуть використовувати його в операційній діяльності, більш ефективно керуючи ризиками, з якими вони стикаються в своїй діяльності, що зробить весь банківський ринок стабільнішим, а вкладників більш захищеними від втрати вкладів через банкрутство банку.

\section{Література:}

1. Азаренкова Г. Анализ динамики финансовых потоков банка с валютной структурной компонентой / Г. Азаренкова, В. Ляшенко / Проблемы и перспективы международных валютно-кредитных и финансовых отношений: монография / под ред. д.э.н., проф. И. 3. Ярыгиной, к.э.н., доц. Т. В. Струченковой. М.: Финансовый университет, 2011. - 240 с. - С. $126-139$.

2. Владичин У.В. Банківське кредитування [Електроний ресурс] : навч. посіб. / У.В. Владичин ; за ред. С.К. Реверчука. - К. : Атіка, 2008. - 648 с. - Режим доступу: http://m.pidruchniki.com/1584072045689/bankivska_sprava/bankivske_kredituvannya (17.08.2016).

3. Вовчак О.Д. Сучасні тенденції ціноутворення на кредитні послуги вітчизняних банків / О.Д. Вовчак // Вісник української академії банківської справи. - 2012. - №2 (33). - С. 4549.

4. Волошин И. В. Динамическая модель денежных потоков идеального процентного банка // Управление риском. - 2007. - № 4(44). - С. 46-50.

5. Волошин І.В. Оцінка оптимальних ставок за роздрібними строковими вкладами банку / I. Волошин, М. Волошин // Вісник НБУ . - 2009. - №12(166) - С.16 - 19. 
6. Волошин I. В. Оптимальне управління роздрібним кредитуванням банку: задача для бізнесінтелідженс-систем // Вісник НБУ. - 2010. - №5(171) - С. 12-15.

7. Волошин І.В. Ціноутворення роздрібних вкладів з урахуванням ризику перевкладення / Волошин І.В. // Вісник Національного банку України. - К.: Національний Банк України, 2011. - №6 (184). - С. 32-35.

8. Волошин М. І. Ціноутворення на роздрібні депозити з урахуванням ризику ліквідності // Банківська справа. - 2013. - №11-12. - С. 86-95.

9. Voloshyn I. Integrated Risk Management in a Commercial Market-Maker Bank Using the "Cash Flow at Risk" Approach. [Електронний pecypc] / I. Voloshyn, M. Voloshyn. - 2013. - Режим доступу: http://dx.doi.org/10.2139/ssrn.2205570.

10. Voloshyn I. Dynamic Pricing on Retail Term Deposits of a Bank [Електронний pecypc] / I. Voloshyn, M. Voloshyn - 2013. - Режим доступу: http://dx.doi.org/10.2139/ssrn.2343033.

11. Voloshyn I. Risk-Adjusted Pricing of Bank's Assets Based on Cash Flow Matching Matrix / I. Voloshyn, M. Voloshyn // ACRN Journal of Finance and Risk Perspectives. - 2013. - Vol. 2, Issue 2. - P. 49-59.

12. Гришин А.Г., Козак Д.В., Умрик А.В., Иваненко В.И., Постановка задачи оптимизации управления коммерческим банком // Вестник Национального технического университета "Харьковский политехнический институт". - Х.: 2001. - ч.2, С. 154-157.

13. Гришин О.Г. Стратегічне планування та керування діяльністю банківської установи на основі математичної моделі комерційного банку // Економіка та підприємництво. КНЕУ. К.: 2004. - Випуск 12, с. 261-266.

14. Іваненко B.I. До управління фінансами в комерційних банках / Іваненко B.I., Куц О.В., Гришин О.Г. // Моделювання та інформаційні системи в економіці. Випуск 84. - К.: КНЕУ, 2011. - C. 220-229.

15. Klein M.A. Theory of banking firm / M.A. Klein // Journal of Money. - Ohio: Ohio State University Press, 1971. - vol. 3. - P. 205-218.

16. Козак О.Ю. Моделювання фінансових потоків комерційного банку / О.Ю. Козак // Проблеми і перспективи розвитку банківської системи України: XIV всеукр. наук.-практ. конф., жовтень 2011 р.: зб. тез доповідей. - Суми: ДВНЗ «УАБС НБУ», 2011. - С. 92 - 93.

17. Monti M. Deposit, credit, and interest rate determination under alternative bank objectives / M. Monti // Mathematical methods of finance. - Amsterdam, North-Holland, 1972 - P. 430-454.

18. Осіпенко Д.В. Динамічна модель комерційного банку // Фінанси України. - 2005. - №11. C. 87-92.

19. Осіпенко Д.В. Динамічна чотирьохконтурна модель комерційного банку: аналіз взаємодії зі страховою компанією // Економічний вісник, Київ, НТУУ КПІ, 2007 (4) - с.194-199

20. Осіпенко Д.В. Розв'язок задачі динамічної оптимізації прибутковості комерційного банку iз застосуванням системи кредитного скорингу // Науково-технічний розвиток: економіка, технології, управління: Матеріали VII Міжнародної науково-практичної конференції студентів, аспірантів і молодих учених 26-29 березня 2008 року. - К.: НТУУ “КПІ”, 2008. C. 260-261.

21. Осіпенко Д.В. Підхід до інтеграції системи кредитного скорингу та моделі керування активами та пасивами комерційного банку / Д.В. Осіпенко // Системні дослідження та інформаційні технології. — 2011. - № 3. - С. 38-47. 